\title{
Specialty preferences and influencing factors: a repeated cross-sectional survey of first- to sixth-year medical students in Jena, Germany
}

\author{
Diana Grasreiner ${ }^{1} \mathbb{D}$, Uta Dahmen ${ }^{1 *}$ and Utz Settmacher ${ }^{2}$
}

\begin{abstract}
Background: Given the expected increase in those entering retirement, the number of practising physicians is predicted to decrease. Conversely, the number of physicians needed is set to increase, due to higher demands resulting from the increasing average age of the German population. This may cause a deficit in the availability and accessibility of medical care for the population in Germany, as well as in other countries.

As such, there needs to be a specific focus on the next generation of physicians. Will they fill the gap in those medical specialties where it is most needed? This study aims to investigate (a) preferences for medical specialties over time and (b) the reasoning behind these preferences among students.

Methods: Over three subsequent years, all medical students from the Jena Faculty of Medicine were repeatedly invited to participate in an online survey. The questionnaire consisted of three parts to explore the students' (1) preferred postgraduate specialty, (2) the reasons for their decision and (3) socio-demographic data. Data analysis was performed using Fisher's exact tests and logistic regression analysis.

Results: The number of students completing the questionnaire in a given year ranged from 180 to 320, resulting in a total number of 720 completed questionnaires. Between 40 and $50 \%$ of the students preferred internal medicine as postgraduate specialty. About $25 \%$ of the students were interested in a surgical specialty. Diagnostics and psychiatric medical fields were preferred by about $10 \%$ of all students for each field in each year of the survey. A large percentage (about 18\%) of the students remained undecided. The factors influencing the students' specialty preferences were most frequently reconciliation of work and family life, career goals as well as predicted workload. The factors depended on the preferred medical specialty.

Conclusion: The influencing factors should be taken into account for recruiting prospective residents. Doing so could increase the chance to attract the number of physicians needed to ensure adequate medical care in the field of interest, according to the growing health needs of the population.
\end{abstract}

Keywords: Postgraduate specialty, Medical student, Influencing factor, Gender, Germany

\footnotetext{
* Correspondence: uta.dahmen@med.uni-jena.de

${ }^{1}$ Klinik für Allgemein-, Viszeral- und Gefäßchirurgie, Experimentelle

Transplantationschirurgie, Universitätsklinikum Jena, Drackendorfer Str. 1,

07747 Jena, Germany

Full list of author information is available at the end of the article
}

(c) The Author(s). 2018 Open Access This article is distributed under the terms of the Creative Commons Attribution 4.0 International License (http://creativecommons.org/licenses/by/4.0/), which permits unrestricted use, distribution, and reproduction in any medium, provided you give appropriate credit to the original author(s) and the source, provide a link to the Creative Commons license, and indicate if changes were made. The Creative Commons Public Domain Dedication waiver (http://creativecommons.org/publicdomain/zero/1.0/) applies to the data made available in this article, unless otherwise stated. 


\section{Background}

The number of practising physicians in Germany is likely to decrease, due to the expected increase in the average age of the German population [1-3]. In addition, the physicians themselves are ageing, and a large proportion of them will retire soon [1, 4-6]. Furthermore, according to the Association of German Surgeons (Bund Deutscher Chirurgen), the rate of students selecting surgery for their postgraduate specialty is declining [7-9].

In contrast, the number of physicians needed is set to increase, due to higher demands from the population in relation to the number and extent of medical treatments $[4,7,10]$. Altogether, this may cause a deficit in the availability and accessibility of healthcare for the population in Germany and other countries. In the UK, the Netherlands, France and Switzerland, as well as nonEuropean countries, such as Canada, Brazil and Saudi Arabia, several surveys have been conducted to explore reasons influencing students in their specialty selection [11-18]. In recent years, work-life balance, selffulfilment and income have often been cited as decisionmaking factors in these publications.

However, the factors influencing the selection of postgraduate medical specialties among German medical students are not well understood [7].

This study aims to investigate (a) the preference for medical specialties over time at the Jena Faculty of Medicine and (b) the reasons for selecting surgery or other medical specialties. In our study, we took a closer look at surgical specialties due to the deteriorating situation in this medical field, which is due, e.g., to difficult working time arrangements and a large proportion of retiring surgeons in Germany [8].

This knowledge could help to improve the recruitment of future physicians in Germany; without an awareness of the influencing factors, they cannot be taken into account when seeking to attract new residents $[19,20]$. Therefore, it is essential to find out if there are any influences from changes in specialty preference over time or gender-related differences.

The study was performed in 2014, 2015 and 2016 at the Jena Faculty of Medicine, when a new curriculum was being implemented. This change was intended to increase the level of practical experience for each student with a special focus on the ambulatory, clinical or research sector. The so-called JENOS project included theoretical and practical teaching and ended with an objective structured clinical examination (OSCE) [21].

\section{Methods}

\section{Study design and distribution}

To answer these questions, we designed a repeated cross-sectional survey. In turn, we invited medical students from the first- to the sixth-year at the Medical
Faculty of Jena in three consecutive years. The students were asked to complete an online questionnaire during a six-week period in the summer semester of 2014, 2015 and 2016 [22].

The survey was generated using SoSciSurvey and mainly distributed electronically via email distributors and additionally through students' Facebook groups according to their year of study. Students registered with the main email distributor for medicine, as well as the email distributor according to their year of study, received two electronic invitations. A reminder was sent after 3 weeks via Facebook.

A pretest was performed to ensure that the items were understandable and unambiguous. Randomly selected students examined the survey, and the questionnaire was revised according to their comments and suggestions. As a result, we adapted the sequence of the questions of the survey.

\section{Questionnaire}

A three-part questionnaire was developed on the basis of a literature review $[19,22,23]$. The first part of the survey asked the students which postgraduate specialty they preferred from a list of 32 possibilities. For statistical analysis purposes, the selected specialties were aggregated into five large groups (internal medicine, surgery, diagnostics, psychiatry and undecided) [Table 1] [24].

In the second part, we explored the reasons underlying their specialty preferences. The participants were asked to select which influencing factors they regarded as important when selecting their specialty. The predefined factors covered characteristics of medical specialties and the personal preferences of the students in terms of their future working life.

In the third part of the survey, we asked for sociodemographic data, such as age, gender and marital status.

Depending on the question, the students' responses were collected using Likert scales, yes/no answers, options menus or free input fields. For each question, two alternatives were available to choose from: "I don't know" or "I don't want to answer this question".

No monetary or other incentive was offered to the participants.

\section{Statistical analysis}

Results were expressed as both absolute numbers and percentages. The response rate was determined by calculating the ratio between the number of completely filled questionnaires and the number of invited participants.

Fisher's exact tests were used to determine whether there were any differences $\left(\mathrm{H}_{1}\right)$ between female and male students concerning the preferred medical specialties or not $\left(\mathrm{H}_{0}\right)$ [Table 2]. 
Table 1 Summary of the five groups of specialties

\begin{tabular}{|c|c|}
\hline \multirow[t]{20}{*}{ Internal medicine } & General medicine \\
\hline & Anaesthesiology \\
\hline & Paediatrics and Youth Medicine \\
\hline & Neurology \\
\hline & Cardiology \\
\hline & Internal medicine \\
\hline & Haematology and Oncology \\
\hline & Physical and Rehabilitation medicine \\
\hline & Endocrinology and Diabetology \\
\hline & Gastroenterology \\
\hline & Nephrology \\
\hline & Pneumology \\
\hline & Rheumatology \\
\hline & Dermatology and Venerology \\
\hline & $\begin{array}{l}\text { Occupational medicine, Public health, } \\
\text { Hygiene and Environmental medicine }\end{array}$ \\
\hline & Angiology \\
\hline & Pharmacology \\
\hline & Clinical Pharmacology \\
\hline & Pharmacology and Toxicology \\
\hline & Radiotherapy \\
\hline \multirow[t]{14}{*}{ Surgery } & Orthopaedics and Trauma surgery \\
\hline & Gynaecology and Obstetrics \\
\hline & Ophthalmology \\
\hline & Heart surgery \\
\hline & Neurosurgery \\
\hline & Abdominal surgery \\
\hline & General surgery \\
\hline & Oral Maxillofacial surgery \\
\hline & Vascular surgery \\
\hline & Paediatric surgery \\
\hline & Otorhinolaryngology \\
\hline & Urology \\
\hline & Thoracic surgery \\
\hline & Plastic and Aesthetic surgery \\
\hline \multirow[t]{5}{*}{ Diagnostics } & Radiology and Nuclear medicine \\
\hline & Forensic medicine \\
\hline & $\begin{array}{l}\text { Laboratory medicine, Human genetics, } \\
\text { Transfusion medicine }\end{array}$ \\
\hline & Microbiology, Virology, Infection epidemiology \\
\hline & Pathology, Neuropathology \\
\hline \multirow[t]{3}{*}{ Psychiatry } & Psychiatry and Psychotherapy \\
\hline & Psychosomatic Medicine and Psychotherapy \\
\hline & $\begin{array}{l}\text { Childhood and Adolescent Psychiatry } \\
\text { and Psychotherapy }\end{array}$ \\
\hline Undecided & I'm still undecided \\
\hline
\end{tabular}

Overview of the medical specialties and to which larger group they belong in our survey
Logistic regression analysis was conducted to investigate the joint effect of the influencing factors. We used the preference for a group of specialties as dependent variable in the regression model, e.g., the students preferred "internal medicine" or they did not prefer this as specialty (yes or no). The explanatory or independent variables of the multivariable analysis were influencing factors, such as "workload", "income" or "reconciliation of work and family life" [Table 3]. In Table 3, the separate logistic regression analyses for the five groups of specialties are shown. In turn, we performed a regression analysis for each of the large groups of specialties, one by one.

The odds ratio (OR), as determined by the logistic regression analysis, was considered as an estimate of the relative risk concerning which factors had and did not have an influence on the students' specialty preference [25]. An indication of the increased or decreased odds was given by the association with the influencing factors (green or red markings in [Table 3]). An OR above the value of 1 was considered as a (positive) influencing factor and an OR below 1 as a factor with a negative or no influence on the students' decision-making process.

The OR is simply the ratio between the following two ratios: The ratio between "the student preferred a particular specialty" and "the student did not prefer a particular specialty", and the ratio between "a positive correlation with an influencing factor" and "a negative correlation with an influencing factor" [26].

A $p$-value $<0.05$ was considered as statistically significant. Statistical data analysis was performed using SPSS version 23 (IBM Corp., Armonk, NY, USA) and Office 2016 version of Excel (Microsoft, Redmond, WA, USA).

\section{Ethical approval}

According to the Ethics Committee of the Jena Faculty of Medicine, formal ethical approval was not needed since anonymity of the participating students and data safety were ensured; nor did the study involve any patient data.

\section{Results}

\section{Response rate and socio-demographic data}

The response rates ranged between $9.2 \%$ and $18.5 \%$ of all medical students in the given year, as shown in Table 4. In total, 720 questionnaires were completed.

The sample population was almost similar to the entire medical student population in Jena and in Germany, in terms of gender and age. Demographic characteristics of the respondents, in comparison to all German medical students, are shown in Table 4. The median age of the participants was 24 years, in the range $18-44$ years, compared to a median age of 24.9 years of the total population of medical students in Jena. 
Table 2 Specialty distribution over a period of three consecutive years [29]

\begin{tabular}{|c|c|c|c|c|c|c|c|c|c|c|c|c|c|c|c|c|c|c|c|c|c|}
\hline \multirow{3}{*}{$\begin{array}{l}\text { Groups of specialties } \\
\text { Internal medicine }\end{array}$} & \multicolumn{7}{|c|}{ Survey 2014} & \multicolumn{7}{|c|}{ Survey 2015} & \multicolumn{7}{|c|}{ Survey 2016} \\
\hline & \multicolumn{2}{|c|}{$\begin{array}{c}\text { Total students } \\
2014(n=325) \\
100 \%\end{array}$} & \multicolumn{2}{|c|}{$\begin{array}{c}\text { Female } \\
\text { students } 2014 \\
(n=234) 72,0 \%\end{array}$} & \multicolumn{2}{|c|}{$\begin{array}{c}\text { Male students } \\
2014(n=88) \\
27,1 \%\end{array}$} & \multirow{2}{*}{$\begin{array}{c}p \\
2014 \\
.453\end{array}$} & \multicolumn{2}{|c|}{$\begin{array}{c}\text { Total students } \\
2015(n=219) \\
100 \%\end{array}$} & \multicolumn{2}{|c|}{$\begin{array}{c}\text { Female } \\
\text { students 2015 } \\
\text { (n=159)72.6\% }\end{array}$} & \multicolumn{2}{|c|}{$\begin{array}{c}\text { Male students } \\
2015(n=58) \\
26.4 \%\end{array}$} & \multirow{2}{*}{\begin{tabular}{|c|}
$\mathrm{p}$ \\
2015 \\
.876 \\
\end{tabular}} & \multicolumn{2}{|c|}{$\begin{array}{c}\text { Total students } \\
2016(n=182) \\
100 \%\end{array}$} & \multicolumn{2}{|c|}{$\begin{array}{c}\text { Female } \\
\text { students } 2016 \\
\text { (n=148) } 81.3 \%\end{array}$} & \multicolumn{2}{|c|}{$\begin{array}{c}\text { Male students } \\
2016(n=33) \\
18.7 \%\end{array}$} & \multirow{2}{*}{\begin{tabular}{|c|}
$p$ \\
2016 \\
.177
\end{tabular}} \\
\hline & $50.8 \%$ & $(n=165)$ & $49.1 \%$ & $(n=115)$ & $54.5 \%$ & $(n=48)$ & & $41.6 \%$ & $(n=91)$ & $40.9 \%$ & $(n=65)$ & $43.1 \%$ & $(n=25)$ & & $48.4 \%$ & $(n=88)$ & $45.9 \%$ & $(n=68)$ & $60.6 \%$ & $(n=20)$ & \\
\hline Family medicine & $13.8 \%$ & $(n=45)$ & $13.7 \%$ & $(n=32)$ & $13.6 \%$ & $(n=12)$ & 1.000 & $13.2 \%$ & $(n=29)$ & $14.5 \%$ & $(n=23)$ & $10.3 \%$ & $(n=6)$ & .505 & $17.6 \%$ & $(n=32)$ & $16.9 \%$ & $(n=25)$ & $21.2 \%$ & $(n=7)$ & .614 \\
\hline Paediatrics & $9.8 \%$ & $(n=32)$ & $12.4 \%$ & $(n=29)$ & $3.4 \%$ & $(n=3)$ & .020 & $7.3 \%$ & $(n=16)$ & $8.8 \%$ & $(n=14)$ & $3.4 \%$ & $(n=2)$ & .247 & $8.8 \%$ & $(n=16)$ & $8.8 \%$ & $(n=13)$ & $9.1 \%$ & $(n=3)$ & 1.000 \\
\hline Anaesthesiology & $10.2 \%$ & $(n=33)$ & $7.3 \%$ & $(n=17)$ & $18.2 \%$ & $(n=16)$ & .007 & $10.0 \%$ & $(n=22)$ & $6.3 \%$ & $(n=10)$ & $20.7 \%$ & $(n=12)$ & .004 & $8.8 \%$ & $(n=16)$ & $6.1 \%$ & $(n=9)$ & $21.2 \%$ & $(n=7)$ & .012 \\
\hline Neurology & $4.0 \%$ & $(n=13)$ & $4.7 \%$ & $(n=11)$ & $2.3 \%$ & $(n=2)$ & .526 & $1.8 \%$ & $(n=4)$ & $2.5 \%$ & $(n=4)$ & $0.0 \%$ & $(n=0)$ & .576 & $3.8 \%$ & $(n=7)$ & $4.7 \%$ & $(n=7)$ & $0.0 \%$ & $(n=0)$ & .353 \\
\hline Surgery & $21.2 \%$ & $(n=69)$ & $22.2 \%$ & $(n=52)$ & $19.3 \%$ & $(n=17)$ & .649 & $26.9 \%$ & $(n=59)$ & $28.3 \%$ & $(n=45)$ & $24.1 \%$ & $(n=14)$ & .608 & $27.3 \%$ & $(n=50)$ & $30.4 \%$ & $(n=45)$ & $15.2 \%$ & $(n=5)$ & .088 \\
\hline Gynaecology & $2.8 \%$ & $(n=9)$ & $3.4 \%$ & $(n=8)$ & $1.1 \%$ & $(n=1)$ & .453 & $4.6 \%$ & $(n=10)$ & $6.3 \%$ & $(n=10)$ & $0.0 \%$ & $(n=0)$ & .066 & $5.5 \%$ & $(n=10)$ & $6.8 \%$ & $(n=10)$ & $0.0 \%$ & $(n=0)$ & .212 \\
\hline $\begin{array}{l}\text { Orthopaedics and } \\
\text { Trauma Surgery }\end{array}$ & $7.4 \%$ & $(n=24)$ & $6.8 \%$ & $(n=16)$ & $9.1 \%$ & $(n=8)$ & .482 & $6.8 \%$ & $(n=15)$ & $6.9 \%$ & $(n=11)$ & $6.9 \%$ & $(n=4)$ & 1.000 & $8.2 \%$ & $(n=15)$ & $7.4 \%$ & $(n=11)$ & $12.1 \%$ & $(n=4)$ & .481 \\
\hline Diagnostics & $5.8 \%$ & $(n=19)$ & $5.6 \%$ & $(n=13)$ & $6.8 \%$ & $(n=6)$ & .791 & $10.0 \%$ & $(n=22)$ & $9.4 \%$ & $(n=15)$ & $10.3 \%$ & $(n=6)$ & .800 & $4.9 \%$ & $(n=9)$ & $4.7 \%$ & $(n=7)$ & $6.1 \%$ & $(n=2)$ & .669 \\
\hline Psychiatry & $3.7 \%$ & $(n=12)$ & $3.0 \%$ & $(n=7)$ & $5.7 \%$ & $(n=5)$ & .320 & $3.7 \%$ & $(n=8)$ & $2.5 \%$ & $(n=4)$ & $6.9 \%$ & $(n=4)$ & .214 & $3.3 \%$ & $(n=6)$ & $3.4 \%$ & $(n=5)$ & $3.0 \%$ & $(n=1)$ & 1.000 \\
\hline Undecided & $18.2 \%$ & $(n=59)$ & $20.1 \%$ & $(n=47)$ & $12.5 \%$ & $(n=11)$ & .143 & $17.4 \%$ & $(n=38)$ & $18.2 \%$ & $(n=29)$ & $15.5 \%$ & $(n=9)$ & .692 & $15.9 \%$ & $(n=29)$ & $15.5 \%$ & $(n=23)$ & $15.2 \%$ & $(n=5)$ & 1.000 \\
\hline
\end{tabular}

Percentages and numbers respectively relate to each year. White fields: Data for the five large groups of medical specialties. Grey fields: Data for some individual medical specialties. Yellow fields: The $p$-values of individual medical specialties with large differences in the specialty preference between female and male students. Purple fields: Percentages of female students preferring surgery

Table 3 Factors for specialty selection

\begin{tabular}{|c|c|c|c|c|c|}
\hline & \multirow[b]{2}{*}{ Influencing factors } & \multirow[b]{2}{*}{$p$-value } & \multirow[b]{2}{*}{$\begin{array}{l}\text { OR Odds } \\
\text { Ratio }\end{array}$} & \multicolumn{2}{|c|}{$95 \%$ confidence interval } \\
\hline & & & & lower value & upper value \\
\hline \multirow{7}{*}{ Internal medicine } & Reconciliation of work and family life & .062 & 1.394 & .983 & 1.977 \\
\hline & Workload & .000 & .446 & .313 & .635 \\
\hline & Career prospects & .001 & .532 & .368 & .771 \\
\hline & Extent of patient contact & .007 & 1.550 & 1.126 & 2.135 \\
\hline & Income & .001 & .467 & .297 & .733 \\
\hline & Reputation & .059 & 1.478 & .985 & 2.219 \\
\hline & Participating in research & .685 & .912 & .583 & 1.425 \\
\hline \multirow{7}{*}{ Surgery } & Reconciliation of work and family life & .000 & .358 & .239 & .537 \\
\hline & Workload & .153 & .727 & .469 & 1.126 \\
\hline & Career prospects & .001 & 1.982 & 1.326 & 2.962 \\
\hline & Extent of patient contact & .022 & .637 & .432 & .938 \\
\hline & Income & .084 & 1.517 & .945 & 2.437 \\
\hline & Reputation & .576 & 1.135 & .729 & 1.767 \\
\hline & Participating in research & .056 & .605 & .361 & 1.014 \\
\hline \multirow{7}{*}{ Diagnostics } & Reconciliation of work and family life & .226 & 1.555 & .761 & 3.174 \\
\hline & Workload & .049 & 1.946 & 1.004 & 3.771 \\
\hline & Career prospects & .305 & 1.423 & .726 & 2.789 \\
\hline & Extent of patient contact & .439 & .781 & .418 & 1.460 \\
\hline & Income & .044 & 2.095 & 1.020 & 4.303 \\
\hline & Reputation & .112 & .501 & .214 & 1.175 \\
\hline & Participating in research & .000 & 3.952 & 1.991 & 7.843 \\
\hline \multirow{7}{*}{ Psychiatry } & Reconciliation of work and family life & .125 & .481 & .189 & 1.224 \\
\hline & Workload & .020 & 2.890 & 1.184 & 7.052 \\
\hline & Career prospects & .722 & 1.196 & .447 & 3.200 \\
\hline & Extent of patient contact & .012 & 3.127 & 1.284 & 7.613 \\
\hline & Income & .995 & .000 & 0.000 & \\
\hline & Reputation & .995 & .000 & 0.000 & \\
\hline & Participating in research & .362 & .494 & .109 & 2.251 \\
\hline \multirow{7}{*}{ Undecided } & Reconciliation of work and family life & .002 & 2.227 & 1.352 & 3.670 \\
\hline & Workload & .000 & 2.860 & 1.847 & 4.428 \\
\hline & Career prospects & .886 & .965 & .589 & 1.580 \\
\hline & Extent of patient contact & .116 & .714 & .469 & 1.087 \\
\hline & Income & .079 & 1.623 & .946 & 2.785 \\
\hline & Reputation & .375 & .769 & .431 & 1.373 \\
\hline & Participating in research & .841 & .937 & .494 & 1.777 \\
\hline
\end{tabular}

Method: The students were asked to decide whether any of the given factors influenced their decision to select a given specialty, and to rate each factor separately. Green cells: Positive attribution. Red cells: Negative attribution. Yellow cells: significant $p$-values 


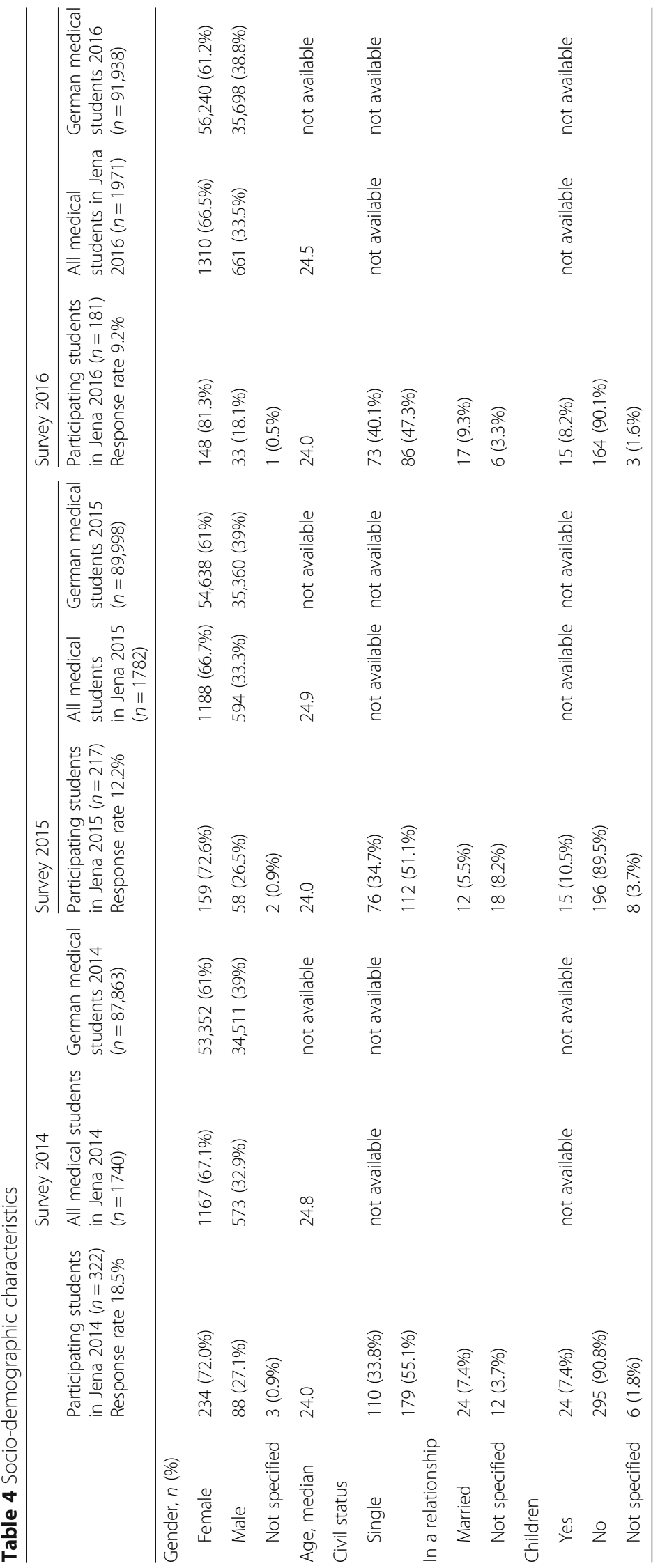


The distribution of socio-demographic data changed slightly over all 3 years. Gender distribution of the participants was unequally distributed, as it is nowadays throughout the whole population of medical students in Germany. Nearly three quarters of the respondents in all 3 years were female. The number of female participants was slightly higher compared to the total population of female medical students from the Jena Faculty of Medicine. Compared to the total population of female medical students in Germany, females in Jena were somewhat over-represented.

\section{Preferred medical fields - general distribution}

Separate analysis of the results from the years 2014, 2015 and 2016 revealed a stable distribution of the preferred medical fields between female and male students [Table 2]. It emerged that about half of the participants were interested in internal medicine, a quarter in surgical fields and about $10 \%$ in diagnostics or psychiatric fields [Fig. 1, Table 2]. A high proportion, i.e., nearly one fifth, of the students were undecided about their future postgraduate specialty. These students could potentially be attracted to under-represented medical fields, if their reasons influencing their decision-making were better understood.

Gender-related differences were found in Anaesthesiology and Paediatrics. The former specialty was preferred more by male students in all 3 years, whereas the latter was preferred more by female students (but only in 2014).

The students preferring surgery were increasingly female, which is in accordance with the findings of the German Medical Statistics Department. This situation could lead to an increasing shortage of surgeons due to family-related employment breaks, although flexible working models could help to address this.

\section{Factors influencing the preference of a given medical specialty}

Besides "reconciliation of work and family life", the factors "workload" and "career prospects" were indicated most frequently as influences on the preference regarding the postgraduate specialty, as shown in Table 3 and in Fig. 2a-e. The reason for preferring one of the specialties in the five main medical groups differed considerably, depending on the selected group.

\section{Internal medicine}

Students preferring internal medicine had a strong positive association with the "extent of patient contact" (OR 1.550) [Fig. 2a, Table 3]. In contrast, they were less influenced by career-related factors such as "workload" (OR 0.446), "career prospects" (OR 0.532) or "income" (OR 0.467) compared to students preferring other specialties.

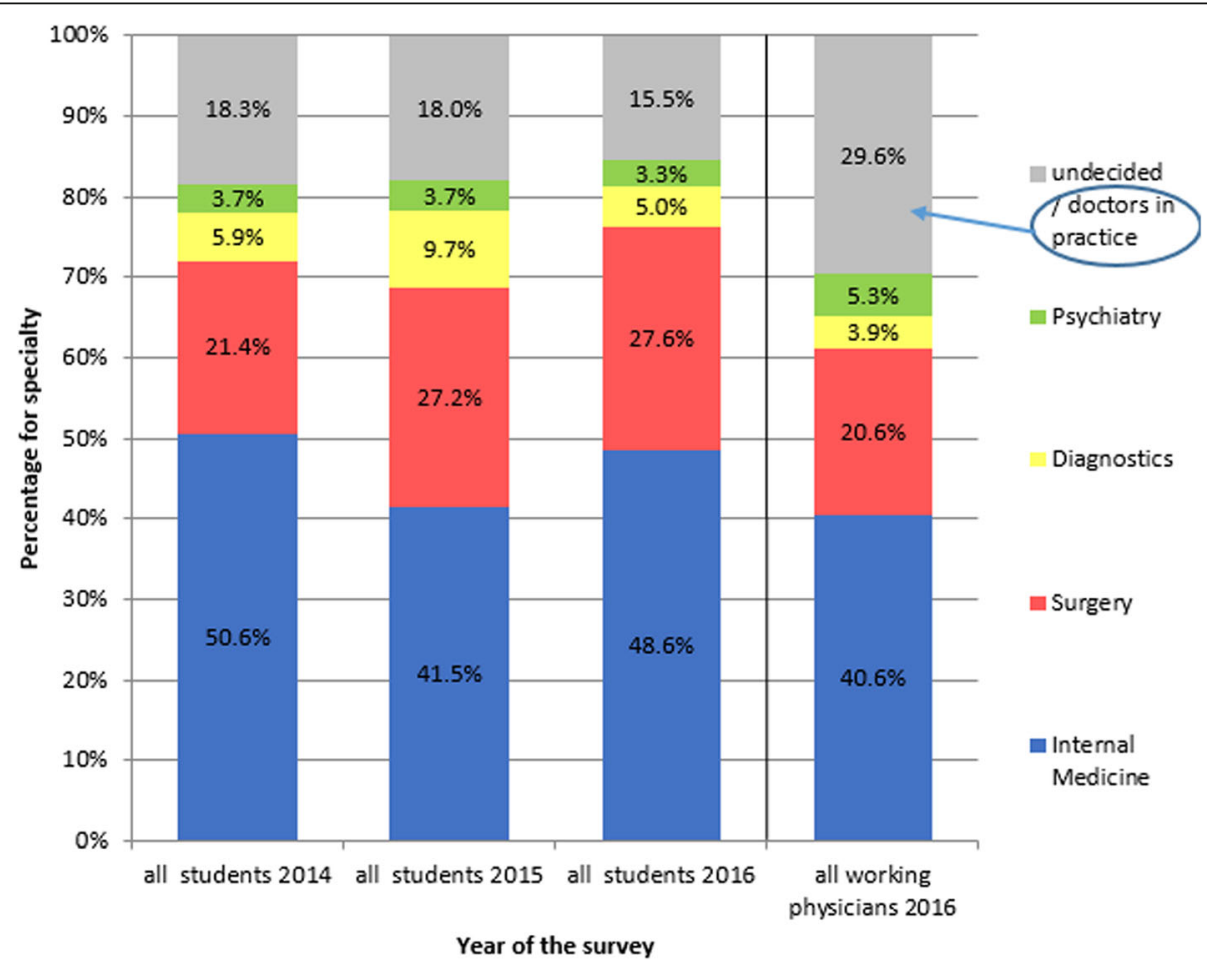

Fig. 1 Specialty selection from 2014 to 2016. Distribution of preferences for medical specialty according to gender and study year [31] 


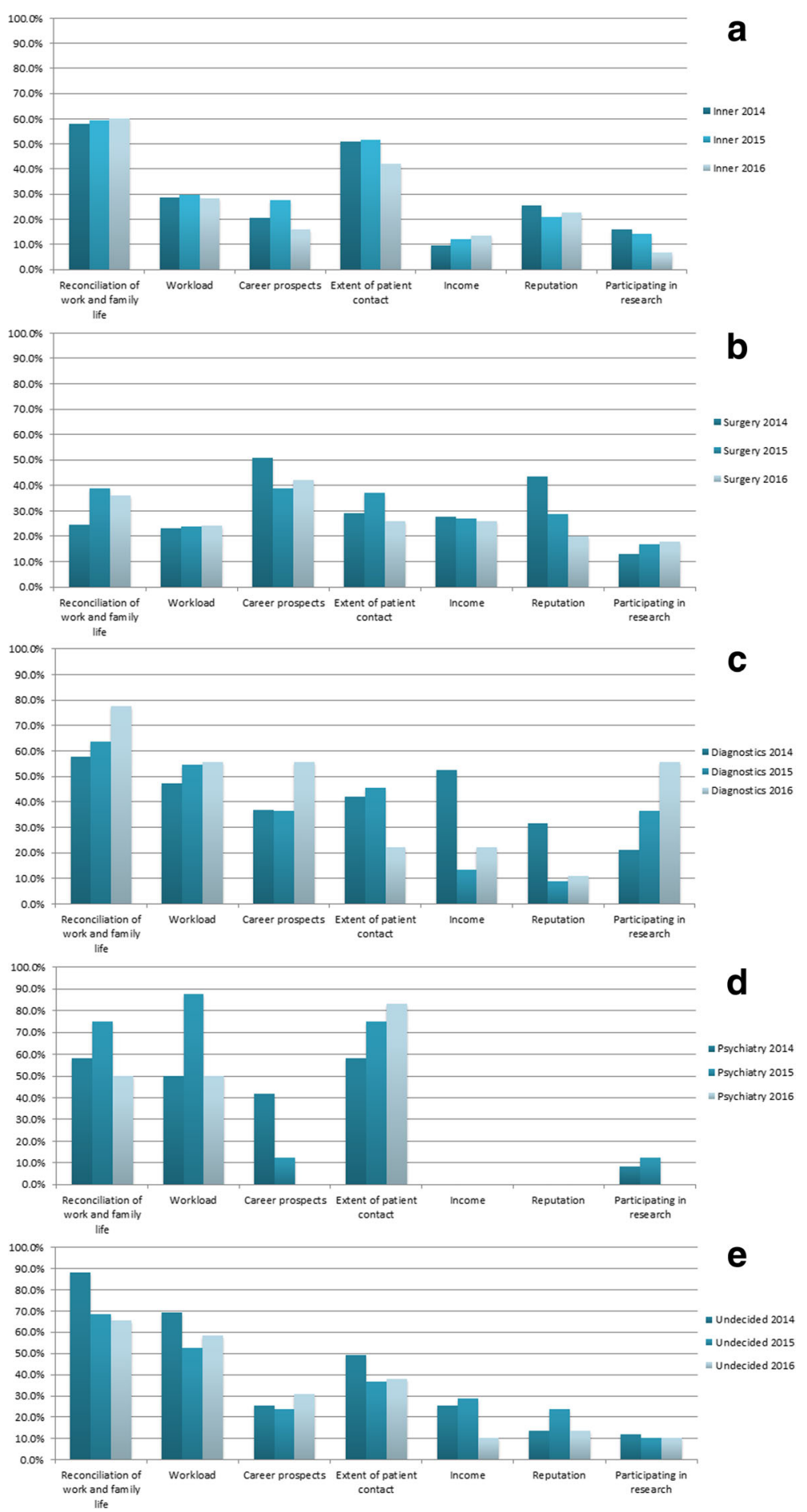

Fig. 2 Influencing factors for 3 years. Distribution of the influencing factors for the five groups of medical specialties for three subsequent years. a Internal medicine. b Surgery. c Diagnostics. d Psychiatry. e Undecided students

\section{Surgery}

Career-associated factors, such as "career prospects" (OR 1.982), were listed by students selecting surgery as strongly influencing their preference [Fig. 2b, Table 3]. In contrast, students preferring other specialties less often rated career-related issues as important in their decision-making.

During all 3 years of the survey, students preferring surgery attached less importance to "reconciliation of work and family life" (OR .358) or to the likely "extent 
of patient contact" (OR .637) compared to students preferring non-surgical specialties [Table 3].

\section{Diagnostics}

It should be emphasized that the students preferring diagnostic specialties rated the possible "participation in research" (OR 3.952) as a strong influencing factor in their decision-making [Fig. 2c, Table 3]. This was not the case with other medical specialties. A large impact was observed in relation to the students' future "income" (OR 2.095), as well as prospective "workload" (OR 1.946).

\section{Psychiatry}

The students who preferred psychiatric specialties acknowledged the "extent of patient contact" (OR 3.127) [Fig. 2d, Table 3] as a strong influencing factor. In almost the same manner, the students reported a strong positive association with their prospective "workload" (OR 2.890).

\section{Undecided students}

The group of undecided students is of special interest. The majority of these students indicated that "reconciliation of work and family life" (OR 2.227) and the expected future "workload" (2.860) were factors of great importance for them, despite having no preferred specialty at the time of the survey [Fig. 2e, Table 3].

The influencing factors of undecided students were in contrast to those of students preferring, for example, surgical medical fields or internal medicine [Table 3].

\section{Discussion}

The present single centre study investigated the preferences among medical students concerning the selection of a postgraduate specialty and their reasons behind this process.

It should be noted that, according to our study, the interest in surgery does not decline during the course of studies, as reported previously by Ansorg et al. [7] and Paulmann et al. [27], but remains constant. Ansorg et al. and Paulmann et al. observed a declining interest in surgical fields, or rather a lower proportion of female students interested in surgical fields. In contrast, Diderichsen et al. [28] reported an unchanged interest, which is in accordance with our results. This is further supported by the national statistics regarding the distribution of board-certified physicians [29-31]. According to the German Federal Statistical Office, the rate of surgeons remained stable at $20 \%$ over the last 16 years [31-33].

\section{Specialty preferences and comparison with working physicians}

According to our results, the distribution of preferred postgraduate specialties among Jena medical students is comparable to the current distribution of specialties among currently working physicians in Germany [Fig. 1]. [29-33]. Selected specialties of the study population were compared to statistics for German physicians [14]. The distribution of medical specialties among board-certified working physicians and the preferences of the students was very similar, suggesting an unchanged interest in the different fields of medicine [see also Table 5] [29-33]. This corresponds to the findings of Diderichsen et al. [28], who stated, in their cross-sectional study, that Swedish medical students show nearly the same preferences in their specialty selection, irrespective of their gender. The proportion of students selecting surgery in Jena increased slightly from $21.4 \%$ in 2014 to $27.6 \%$ in 2016 . If our results hold true, the potential shortage of surgeons would be limited to what is required in order to meet the growing demand from a population with increasing age and healthcare needs. As female students outnumbered male students, the shortage in surgical residents due to family-related absences requires a rethink regarding working time models in understaffed medical fields $[4,7]$.

The group of undecided students is of particular interest, because of the possible recruitment of these students in medical specialties with a shortage of residents. According to Al-Fouzan et al. [22], the proportion of undecided students could be diminished with the help of formal career counselling during medical school. This could be implemented according to the Canadian guidelines [34]. An optimal time to perform career counselling is the end of the clinical part of studies, as well as the beginning of the residency, which could be carried out as individual counselling or as a group event, especially for disadvantaged students [35]. In addition, there may be a lack of role models in some understaffed specialties [5, 36]. Role models are characterized by their expertise and, in particular, their approachability [36].

In our study, the reasons rated as important by the majority of undecided students were different to the reasons given by students primarily interested in surgery. Consequently, the factors "workload" and "reconciliation of work and family life" should be taken into account when trying to attract currently undecided students into potentially under-represented specialties, such as surgery. In other words, special effort should be focused on offering suitable working conditions to this cohort of students.

\section{Factors influencing specialty selection}

We identified the factors influencing the selection of postgraduate medical specialties including personal 
Table 5 Summary of working physicians

\begin{tabular}{|c|c|c|c|c|c|c|c|c|c|c|}
\hline $\begin{array}{c}\text { Groups of } \\
\text { specialties }\end{array}$ & $\begin{array}{c}\text { Working physicians } \\
\mathbf{2 0 0 0} \\
(\mathrm{n}=294676)\end{array}$ & \multicolumn{2}{|c|}{$\begin{array}{c}\text { Working physicians } \\
\mathbf{2 0 1 0} \\
(\mathrm{n}=333599)\end{array}$} & \multicolumn{2}{|c|}{$\begin{array}{c}\text { Working physicians } \\
\mathbf{2 0 1 4} \\
(\mathrm{n}=365247)\end{array}$} & \multicolumn{2}{|c|}{$\begin{array}{c}\text { Working physicians } \\
\mathbf{2 0 1 5} \\
(\mathrm{n}=371302)\end{array}$} & \multicolumn{2}{|c|}{$\begin{array}{c}\text { Working physicians } \\
\mathbf{2 0 1 6} \\
(\mathrm{n}=378607)\end{array}$} \\
\hline $\begin{array}{c}\text { Internal } \\
\text { medicine } \\
\text { (Family } \\
\text { medicine) }\end{array}$ & 120564 & $\mathbf{4 0 . 9 \%}$ & 135709 & $40.7 \%$ & 146284 & $40.0 \%$ & 150779 & $40.6 \%$ & 153633 & $40.6 \%$ \\
\hline Surgery & 56906 & $12.5 \%$ & 43.103 & $12.9 \%$ & 43.206 & $11.8 \%$ & 43569 & $11.7 \%$ & 43618 & $11.5 \%$ \\
\hline Diagnostics & 10501 & $3.6 \%$ & 12719 & $3.8 \%$ & 14648 & $4.0 \%$ & 14466 & $3.9 \%$ & 14862 & $3.9 \%$ \\
\hline Psychiatry & 14464 & $4.9 \%$ & 17882 & $5.4 \%$ & 19323 & $5.3 \%$ & 19809 & $5.3 \%$ & 20088 & $5.3 \%$ \\
\hline $\begin{array}{c}\text { Without } \\
\text { specialist } \\
\text { examination }\end{array}$ & 76580 & $26.0 \%$ & 98346 & $29.5 \%$ & 110227 & $30.3 \%$ & 109543 & $29.5 \%$ & 111850 & $29.5 \%$ \\
\hline Others & 15661 & $5.3 \%$ & 388 & $0.1 \%$ & 379 & $0.1 \%$ & 387 & $0.1 \%$ & 365 & $0.1 \%$ \\
\hline
\end{tabular}

Chronological sequence of working physicians highlighting the steady increase in the number of female surgeons. White fields: Data for the five large groups of medical specialties. Grey fields: Data for an individual medical specialty

motivations, career-associated reasons and work-life balance. Personal aspects of future life planning and characteristics attributed to a given specialty had a large influence on the selection of the postgraduate specialty.

Characteristics commonly attributed to surgery include promising career prospects, high workload and good reputation. Kiolbassa et al. [19] also stated that students selecting surgery are more concerned about their career prospects and their reputation than students selecting other disciplines. These characteristics were also the key influencing factors among students selecting surgery as their postgraduate specialty in our study, as well as in the survey conducted by Khader et al. and other studies [18, 19, 28, 37-41]. According to Khader et al. [37], in the main, male students preferring surgery were highly influenced by factors such as prestige and income, whereas females did not rate these factors as being of the utmost importance.

In contrast, Kaderli et al. [42] and others [5, 19, 43] stated that factors such as work-life balance and family planning do not equate with seeking a undemanding lifestyle, but with having the time to fulfil life goals besides work [42]. Consequently, surgery is less often selected by students who attach importance to family life, as a complement to their working life. These students tend to select internal medicine, diagnostics or psychiatry as their preference. Similar results have also been reported in studies by Alers et al., Takeda et al. and others [18, 19, 44-47]. According to Alers et al. [45], Diderichsen et al. [28] and Harries et al. [48], female physicians tend to work part-time more than their male colleagues. These women often select disciplines such as general medicine or internal medicine because they associate them with family friendliness [28, 45]. Takeda et al. [46] and Correia Lima de Souza et al. [15] stated that surgical specialties (surgery, neurosurgery) were associated with having little time for the fulfilment of life goals, whereas other specialties such as ophthalmology, radiology or dermatology allowed time for personal goals. In particular, more female students would prefer to work part-time compared with male students $[28,48]$. Consequently, female students follow a different reasoning process in the selection of a specific specialty than male students. Furthermore, the feminisation of medicine, and in particular of surgery, would require a change in thinking about work-life balance, modern working time models, and the participation of females in leadership and research [49].

In summary, the preferences of the medical students in our study almost reflect the distribution of future physicians across Germany [Table 2] [1]. Therefore, the influencing factors for the decision-making process should be taken into greater consideration when addressing a shortage of physicians in certain specialties [50, 51]. For instance, improved working conditions would be required to accommodate the wish for a sustained work-life balance [27, 31]. This would be essential not only to attract students into underrepresented medical fields at the postgraduate specialty stage, but also to help them complete their residency and enable them to pursue a successful career as a physician. However, our results confirm that there is a need for the introduction of more flexible working models, career counselling at an appropriate stage during studies, and good mentoring interventions for residents.

\section{Strengths}

This study was conducted at a single medical school in Germany, but as a repeated cross-sectional study addressing all students repeatedly over 3 years. This design has both strengths and limitations. Including 
other medical schools could have provided a better representation of the study population. However, our sample population had a similar gender and age distribution as nationally reported, suggesting a satisfactory representation.

\section{Conclusion}

According to our study, the interest in different medical specialties remained stable regarding the gender of the students who participated. The decision-making process was found to be affected by the desire to achieve a work-life balance, allowing for career and family commitments to be reconciled.

Our results suggest that extra effort should be focused on adapting working conditions to ensure that pursuing both goals in life is supported. Doing so could help students who are already interested in under-represented medical fields to realize their professional goal, as well as encourage undecided students to consider this specialty. This, in turn, could increase the possibility of recruiting the number of physicians needed to ensure adequate medical care according to the growing demands of the German population.

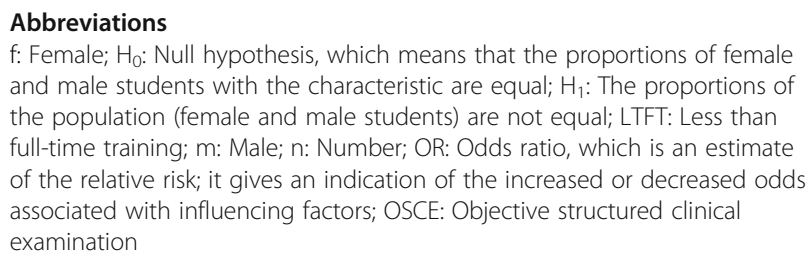

f: Female; $\mathrm{H}_{0}$ : Null hypothesis, which means that the proportions of female and male students with the characteristic are equal; $\mathrm{H}_{1}$ : The proportions of the population (female and male students) are not equal; LTFT: Less than full-time training; m: Male; n: Number; OR: Odds ratio, which is an estimate of the relative risk; it gives an indication of the increased or decreased odds associated with influencing factors; OSCE: Objective structured clinical examination

\section{Acknowledgements}

We are grateful to Dr. rer. Pol. Thomas Lehmann for his support with statistical issues.

Furthermore, we have to express our appreciation to all the students who participated in the survey and shared their opinions with us.

\section{Availability of data and materials}

The data sets used and/or analysed during the current study are available from the corresponding author on reasonable request.

\section{Authors' contributions \\ DG designed and distributed the online survey, collected and analysed the data, and drafted the manuscript. UD developed the study, supervised the generation of the survey and the writing of the manuscript. US participated in the design of the survey and coordination of the study. All authors read and approved the final manuscript.}

\section{Ethics approval and consent to participate}

According to the Ethics Committee of the Jena Faculty of Medicine, formal ethical approval was not needed since anonymity of the participating students and data safety were ensured; nor did the study involve any patient data.

Study participants completed an electronic informed consent form before beginning the survey.

\section{Competing interests}

The authors declare that they have no competing interests.

\section{Publisher's Note}

Springer Nature remains neutral with regard to jurisdictional claims in published maps and institutional affiliations.

\section{Author details}

${ }^{1}$ Klinik für Allgemein-, Viszeral- und Gefäßchirurgie, Experimentelle Transplantationschirurgie, Universitätsklinikum Jena, Drackendorfer Str. 1, 07747 Jena, Germany. ${ }^{2}$ Klinik für Allgemein-, Viszeral- und Gefäßchirurgie, Universitätsklinikum Jena, Am Klinikum 1, 07747 Jena, Germany.

Received: 28 August 2017 Accepted: 20 April 2018

Published online: 09 May 2018

\section{References}

1. Schmidt K, Meyer JE, Liebeneiner J, Schmidt CE, Huttenbrink KB. The shortage of qualified staff in Germany: a survey on head physicians' expectations of young doctors. HNO. 2012;60(2):102-8.

2. Natanzon I, Szecsenyi J, Ose D, Joos S. Future potential country doctor: the perspectives of German GPs. Rural Remote Health. 2010;10(2):1347.

3. Kopetsch T. Dem deutschen Gesundheitswesen gehen die Ärzte aus! (The German Social Security System runs out of doctors). Berlin: Bundesärztekammer und Kassenärztliche Bundesvereinigung; 2010.

4. Papenfuß T, Roch C. Ärztemangel am Beispiel der Anästhesie und Intensivmedizin (Shortage of doctors in anaesthesia). Anästhesiol Intensivmed Notfallmed Schmerzther. 2012;47:352-7.

5. Weise K, Niethard FU. On the lack of young physicians in trauma surgery and orthopaedics. Z Orthop Unfall. 2010;148(1):17-8.

6. Salsberg E, Grover A. Physician workforce shortages: implications and issues for academic health centers and policymakers. Acad Med. 2006:81(9):782-7.

7. Ansorg J. Nachwuchsmangel und Nachwuchsförderung in der Chirurgie (Shortage and development of residents in surgery): BDC; 2010;49(6):296.

8. Kleinert R, Fuchs C, Romotzky V, Knepper L, Wasilewski ML, Schroder W, Bruns C, Woopen C, Leers J. Generation $Y$ and surgical residency - passing the baton or the end of the world as we know it? Results from a survey among medical students in Germany. PLoS One. 2017;12(11):e0188114.

9. Van den Bussche H, Ziegler S, Krause-Solberg L, Scherer M. Stability and change of medical specialty of residents over four years of postgraduate training in Germany. Gesundheitswesen. 2017;79(10):865-70.

10. Ganschow P. Attitude of medical students towards a surgical career - a global phenomenon? Zentralbl Chir. 2012;137(2):113-7.

11. Nicholson S, Hastings AM, McKinley RK. Influences on students' career decisions concerning general practice: a focus group study. Br J Gen Pract. 2016;66(651):e768-75.

12. McDonald $P$, Jackson $B$, Alberti $H$, Rosenthal J. How can medical schools encourage students to choose general practice as a career? Br J Gen Pract. 2016;66(647):292-3.

13. Pianosi K, Bethune C, Hurley KF. Medical student career choice: a qualitative study of fourth-year medical students at memorial university, Newfoundland. CMAJ Open. 2016;4(2):E147-52.

14. Woolf K, Elton C, Newport M. The specialty choices of graduates from Brighton and Sussex Medical School: a longitudinal cohort study. BMC Med Educ. 2015;15:46.

15. Correia Lima de Souza L, Mendonca VR, Garcia GB, Brandao EC, Barral-Netto M. Medical specialty choice and related factors of Brazilian medical students and recent doctors. PLoS One. 2015;10(7):e0133585.

16. Mehmood SI, Kumar A, Al-Binali A, Borleffs JC. Specialty preferences: trends and perceptions among Saudi undergraduate medical students. Med Teach. 2012;34(Suppl 1):S51-60.

17. Lefevre JH, Roupret M, Kerneis S, Karila L. Career choices of medical students: a national survey of 1780 students. Med Educ. 2010;44(6):603-12.

18. Buddeberg-Fischer B, Klaghofer R, Abel T, Buddeberg C. Swiss residents' speciality choices - impact of gender, personality traits, career motivation and life goals. BMC Health Serv Res. 2006;6:137.

19. Kiolbassa K, Miksch A, Hermann K, Loh A, Szecsenyi J, Joos S, Goetz K. Becoming a general practitioner - which factors have most impact on career choice of medical students? BMC Fam Pract. 2011;12:25.

20. Kasch R, Engelhardt M, Forch M, Merk H, Walcher F, Frohlich S. Physician shortage: how to prevent generation $Y$ from staying away - results of a nationwide survey. Zentralbl Chir. 2016;141(2):190-6. 
21. JENOS (Tendency-orientated curriculum at the Jena Faculty of Medicine). https://www.uniklinikum-jena.de/studiendekanat/jenos.html. Accessed 6 May 2018.

22. Knox KE, Getzin A, Bergum A, McBride P, Rieselbach R, Friedsam D. Short report: factors that affect specialty choice and career plans of Wisconsin's medical students. Wis Med J. 2008;107(8):370-3.

23. Chang PY, Hung CY, Wang Kl, Huang YH, Chang KJ. Factors influencing medical students' choice of specialty. J Formos Med Assoc. 2006;105(6):489-96.

24. German Medical Association, List of possible medical specialties. http:// www.bundesaerztekammer.de/aerzte/aus-weiter-fortbildung/weiterbildung/ muster-logbuecher/. Accessed 6 May 2018.

25. Petrie A, Sabin C. Medical statistics at a glance, Vol. 3: Wiley; 2009. ISBN: 9781-405-18051-1.

26. The odds ratio: calculation, usage, and interpretation. http://www. biochemia-medica.com/content/odds-ratio-calculation-usage-andinterpretation. Accessed 6 May 2018.

27. Paulmann V, Fischer $V$, Dudzinska A, Pabst R. Surgery as specialization for female physicians: results from course evaluations and alumni studies at MHH. Chirurg. 2015;86(6):595-602.

28. Diderichsen S, Johansson EE, Verdonk P, Lagro-Janssen T, Hamberg K. Few gender differences in specialty preferences and motivational factors: a cross-sectional Swedish study on last-year medical students. BMC Med Educ. 2013;13:39.

29. Ärztestatistik 2014: Etwas mehr und doch zu wenig (Statistics from the German Medical Association). http://www.bundesaerztekammer.de/ueberuns/landesaerztekammern/aktuelle-pressemitteilungen/news-detail/ aerztestatistik-2014-etwas-mehr-und-doch-zu-wenig/. Accessed 6 May 2018.

30. Ärztestatistik 2015: Medizinischer Versorgungsbedarf steigt schneller als die Zahl der Ärzte (Statistics from the German Medical Association). http://www. bundesaerztekammer.de/ueber-uns/aerztestatistik/aerztestatistik-2015/. Accessed 6 May 2018.

31. Ärztestatistik 2016: Die Schere zwischen Behandlungsbedarf und Behandlungskapazitäten öffnet sich (Statistics from the German Medical Association). http://www.bundesaerztekammer.de/ueber-uns/aerztestatistik/ aerztestatistik-2016/. Accessed 6 May 2018.

32. Ärztestatistik 2000 (Statistics from the German Medical Association). http:// www.bundesaerztekammer.de/ueber-uns/aerztestatistik/aerztestatistik-dervorjahre/aerztestatistik-2000/ergebnisse-der-aerztestatistik-zum-31dezember-2000/. Accessed 6 May 2018.

33. Ärztestatistik 2010 (Statistics from the German Medical Association). http:// www.bundesaerztekammer.de/ueber-uns/aerztestatistik/aerztestatistik-dervorjahre/aerztestatistik-2010/. Accessed 6 May 2018.

34. Howse K, Harris J, Dalgarno N. Canadian national guidelines and recommendations for integrating career advising into medical school curricula. Acad Med. 2017;92(11):1543-8.

35. Frei E, Stamm M, Buddeberg-Fischer B. Mentoring programs for medical students - a review of the PubMed literature 2000-2008. BMC Med Educ. 2010;10:32.

36. Stahn B, Harendza S. Role models play the greatest role - a qualitative study on reasons for choosing postgraduate training at a university hospital. GMS Z Med Ausbild. 2014;31(4):Doc45.

37. Khader Y, Al-Zoubi D, Amarin Z, Alkafagei A, Khasawneh M, Burgan S, El Salem K, Omari M. Factors affecting medical students in formulating their specialty preferences in Jordan. BMC Med Educ. 2008:8:32.

38. Ibrahim M, Fanshawe A, Patel V, Goswami K, Chilvers G, Ting M, Pilavakis Y, Rao C, Athanasiou T. What factors influence British medical students' career intentions? Med Teach. 2014;36(12):1064-72.

39. Rehman A, Rehman T, Shaikh MA, Yasmin H, Asif A, Kafil H. Pakistani medical students' specialty preference and the influencing factors. J Pak Med Assoc. 2011;61(7):713-8

40. Erraji M, Kharraji A, Abbasi N, Najib A, Yacoubi H. Why medical students choose orthopedic surgery as a specialty? Pan Afr Med J. 2015:20:364.

41. Baschera D, O'Donnell Taylor E, Masilonyane-Jones T, Isenegger P, Zellweger R. Are medical students who want to become surgeons different? An international cross-sectional study. World J Surg. 2015;39(12):2908-18.

42. Kaderli R, Buser C, Stefenelli U, Businger A. Students' interest in becoming a general surgeon before and after a surgical clerkship in German-speaking Switzerland. Swiss Med Wkly. 2011;141:w13246.
43. Reed CE, Vaporciyan AA, Erikson C, Dill MJ, Carpenter AJ, Guleserian KJ, Merrill WH. Factors dominating choice of surgical specialty. J Am Coll Surg. 2010;210(3):319-24.

44. Chew YW, Rajakrishnan S, Low CA, Jayapalan PK, Sreeramareddy CT. Medical students' choice of specialty and factors determining their choice: a crosssectional questionnaire survey in Melaka-Manipal medical college, Malaysia. BioScience Trends. 2011;5(2):69-76.

45. Alers M, Pepping $T$, Bor $H$, Verdonk P, Hamberg K, Lagro-Janssen A. Speciality preferences in Dutch medical students influenced by their anticipation on family responsibilities. Perspect Med Educ. 2014;3(6):443-54.

46. Takeda Y, Morio K, Snell L, Otaki J, Takahashi M, Kai I. Characteristic profiles among students and junior doctors with specific career preferences. BMC Med Educ. 2013;13:125.

47. Lefevre JH, Karila L, Kerneis S, Roupret M. Motivation of French medical students to pursue surgical careers: results of national survey of 1742 students. J Visc Surg. 2010;147(3):e181-6.

48. Harries RL, Gokani VJ, Smitham P, Fitzgerald JE, on behalf of the councils of the Association of Surgeons in Training and the British Orthopaedic Trainees Association. Less than full-time training in surgery: a cross-sectional study evaluating the accessibility and experiences of flexible training in the surgical trainee workforce. BMJ Open. 2016;6(4):e010136.

49. Hasebrook J, Hahnenkamp K, Buhre W, de Korte-de Boer D, Hamaekers AEW, Metelmann B, Metelmann C, Bortul M, Palmisano S, Mellin-Olsen J, et al. Medicine goes female: protocol for improving career options of females and working conditions for researching physicians in clinical medical research by organizational transformation and participatory design. JMIR Res Protoc. 2017;6(8):e152.

50. Alers M, van Leerdam L, Dielissen P, Lagro-Janssen A. Gendered specialities during medical education: a literature review. Perspect Med Educ. 2014;3(3):163-78.

51. Bath MF, Harries RL, Gokani VJ. Medical students' and interns' interest in orthopedic surgery: the gender factor. J Surg Educ. 2017;74(1):1.

\section{Ready to submit your research? Choose BMC and benefit from:}

- fast, convenient online submission

- thorough peer review by experienced researchers in your field

- rapid publication on acceptance

- support for research data, including large and complex data types

- gold Open Access which fosters wider collaboration and increased citations

- maximum visibility for your research: over $100 \mathrm{M}$ website views per year

At BMC, research is always in progress.

Learn more biomedcentral.com/submissions 